\title{
Geological Hazards in Loess Induced by Agricultural Irrigation in Arid and Semiarid Regions of China
}

\author{
Yuan-jun Xu $\mathbb{D}$, Jia-ding Wang $\mathbb{D}$, Tian-feng Gu $\mathbb{D}$, and Jia-xu Kong $\mathbb{1}$ \\ State Key Laboratory of Continental Dynamics, Department of Geology, Northwest University, Xi'an, Shaanxi 710069, China \\ Correspondence should be addressed to Jia-ding Wang; wangjiading029@163.com
}

Received 12 July 2020; Revised 18 August 2020; Accepted 30 October 2020; Published 23 November 2020

Academic Editor: Hossein Moayedi

Copyright (C) 2020 Yuan-jun Xu et al. This is an open access article distributed under the Creative Commons Attribution License, which permits unrestricted use, distribution, and reproduction in any medium, provided the original work is properly cited.

\begin{abstract}
The development of agriculture in the arid and semiarid regions of China mainly depends on agricultural irrigation. Until 2016, water required for agricultural irrigation has accounted for more than $90 \%$ of the total water consumption. But traditionally extensive broad irrigation causes frequent loess geological hazards in irrigation area and it threatens security of local life and property. In this paper, we selected the Heifangtai irrigation district in Yonging County, Gansu Province, where frequent instabilities occur, as the study area. We used laboratory tests and numerical simulation to examine the mechanism of loess landslides owing to the irrigation hydrological cycle. Irrigation changes the local natural hydrogeological conditions because of the loose and macroporous structure of loess. The numerous pores and fissures constitute preferential migration pathways of irrigation water; thus, irrigation can increase the groundwater level and hydraulic gradient. Broad irrigation is the main inducing factor of geological hazards (including landslides, collapses, and soil salinization) in arid and semiarid regions, and the development of fissures and sinkholes increases the risk of landslides. New water-saving irrigation methods need to replace the traditional irrigation methods and improve the utilization of water resources. A monitoring and warning system in susceptible areas should be established to ensure the sustainability of local agriculture.
\end{abstract}

\section{Introduction}

China needs to feed a quarter of the world's population using $7 \%$ of the available agricultural land. However, $49 \%$ of the agricultural land in China is in arid and semiarid regions, with temperate continental climate $[1,2]$. Annual precipitation is less than $400 \mathrm{~mm}$ and gradually decreases from east to west. There are only few inland rivers and most of them are seasonal. The growth of crops depends on ample water and solar radiation, but high temperature, less rainfall, and extreme weather have pernicious effect on agricultural production [3]. Because of the population increase in China, the normalization of agricultural irrigation was realized in most agricultural areas of China $[4,5]$; however, traditional broad irrigation is still the main irrigation method in west China. This irrigation method drastically increases agricultural production and changes the water balance of the irrigated district, which also causes the underground water level in the irrigated district to rise. Therefore, geologic hazards induced by broad irrigation increase in frequency [6-9], and this restricts the development of new-type urbanization and regional society economy, even impedes economic development of Silk Road Economic Belt.

The change of the local hydrogeological conditions caused by long-term broad irrigation is the main induced factor of geological disasters. The local geological environment favours landslides. Therefore, it is necessary to study the mechanism of loess irrigation infiltration to analyze the geological hazards of loess irrigation. Water migration pathways greatly affect the seepage of irrigation water. Beven and German [10] first proposed the theory of soil superiority flow; the influence of preferential migration pathway on the infiltration and diffusion of surface water was studied through experimental validation and theoretical analysis. German and Beven [11] presented a method for evaluating the effect of micropores on infiltration capacity by using the concept of the soil-water potential. Theoretical and numerical models were used to study the inflow infiltration 
mode, controlling factors, the spatial distribution, and water migration patterns of preferential migration runoff [12]. Xu et al. [13] argued that the infiltration of broad irrigation water through preferential migration pathways increased the groundwater level and it was the main reason for fast mass slides in remote areas. Loess landslides induced by irrigation are attributed to the water seepage in slopes that increases the sliding force and decreases the sliding resistance [14]. Hutchinson [15] proposed that soil landslides are induced by irrigation because of structural deterioration and increase in pore pressure and liquefaction. Sassa [16] further pointed out that more than $85 \%$ saturation is sufficient to produce excess pore water pressure, leading to landslides. Wang and Hui [17-19] argued that irrigation infiltration increases the pore water pressure but also decreases the permeability; thus, pore water pressure does not dissipate and landslides occur. Wang $[20,21]$ proposed that creep and liquefaction in saturated loess are responsible for landslides. Previous research was mainly on water infiltration and soil behavior $[22,23]$ and the relation between groundwater level and landslides [24]. However, the effect of irrigation on slope hydrology is a long-term process; the current method is mainly on-site monitoring, which needs a long time. This paper uses numerical analysis and indoor unsaturated test to explore the mechanism of loess landslide in irrigation area.

The paper mainly studies the landslides in loess induced by irrigation in arid and semiarid regions by using laboratory tests and numerical simulation. The research area is Heifangtai platform, which is known as the natural laboratory of landslides. Methods to control landslides induced by irrigation were also proposed. The test results and conclusions derived in this study will provide scientific guidance for the prevention and warning of the loess geological disasters induced by agricultural irrigation in arid and semiarid regions of China.

\section{Irrigation and Geological Hazards in Arid and Semiarid Region}

With the development of engineering technology, massive hydraulic projects aimed to foster agricultural development of arid regions in the middle and lower reaches of the Yellow River and its tributaries. Traditional agricultural irrigation methods are surface irrigation (border irrigation, furrow irrigation, basin irrigation, and broad irrigation), general irrigation, and microirrigation. Agriculture in the arid and semiarid regions of northwestern China mainly depends on agricultural irrigation owing to topography and climate [25]. However, long-term use of broad irrigation wastes freshwater resources (China Water Resources Bulletin, 2004-2016). Agricultural water accounts for more than $90 \%$ of the used water in northwestern China (Table 1 and Figure 1).

Long-term surface irrigation increases the supply of groundwater, which changes the local hydrogeological conditions and induces landslides, collapses, and mudflows. Geological hazards in loess area induced by irrigation are mainly distributed in the Shaanxi, Gansu, Ningxia, Qinghai, Henan, and Shanxi Provinces, especially, along the Jinghe,
Weihe, and Huangshuihe Rivers and their tributaries. Groups of ribbon-like landslides often stretch to tens of kilometres. Typically, geological hazards in loess induced by broad irrigation occur in the Jingyang south plateau of Shaanxi Province $[26,27]$ and the Heifangtai tableland of Gansu Province [28, 29]. Mountain forests around cities need sprinkle irrigation that can cause landslides, such as the Yikeyin landslide in Xi'ning Province [30] and Wenmiao landslide in Lanzhou City. Canal seepage is ubiquitous in irrigated areas, causing loess collapse and landslides, e.g., Gaolou landslide in Huaxian, Shaanxi Province [31]. Geological hazards in loess threaten human lives and incur property damages, negatively affecting the local economies.

2.1. Irrigation and Agriculture in Heifangtai Tableland. The paper takes Heifangtai irrigation in Liujiaxia reservoir and Yanguoxia reservoir area as typical irrigation area to state the development of agriculture in irrigation area. The Heifangtai tableland is a typical loess landscape with no water and thus economically backward. Since 1963, reservoir resettlement of Liujiaxia, Yanguoxia, and Bapanxia reservoir has been moved to Heifangtai tableland. To provide agricultural and drinking water for the migration, three pumping engineering projects (Figure 2) were successively built during July 1966 to June 1969. Lifting irrigation takes place five times a year in the irrigation area. Spring irrigation occurs from March to May, winter irrigation from November to December, and three times irrigation of young crops. Recently, the Heifangtai area is the most important vegetable- and fruit-producing area in the Lanzhou district. There has been a structural adjustment of agricultural production from traditional food crops, such as wheat and maize, to high-yielding crops, such as fruits and vegetables. Therefore, agricultural irrigation has significantly increased, and the irrigation channel system has become denser (Figure 3). Except for spring and winter irrigation, the irrigation of young crops has increased to five times a year and the annual mean irrigation volume of the Fangtai tableland has increased to $5.909 \times 10^{4} \mathrm{~m}^{3}$, with frequent broad irrigation (Figure 2(b)). The yearly irrigations are not equally distributed but depend on water need and rainfall. The annual mean irrigation quota per square kilometer is $838.56 \mathrm{~m}^{3}$ according to the latest actual irrigation area $\left(0.705 \mathrm{~km}^{2}\right)$. The maximal evapotranspiration of the farmland is $880 \mathrm{~mm}$ (including ground surface evaporating and leaf transpiration) and the supplementary irrigation for crops is $657.6 \mathrm{~mm}$ after deducting the maximal evapotranspiration of the farmland. Moreover, the annual mean irrigation volume is $4.98 \times 106 \mathrm{~m}^{3}$. In other words, the irrigation of the Heitai tableland exceeds by $20 \%$ the water needs of the Heifangtai tableland in schedule except for the irrigation of the Fangtai tableland.

2.2. Irrigation Water Infiltration. The mode of irrigation water infiltration and effect on groundwater are shown in Figure 4. The climate in the Heifangtai loess plateau is arid to semiarid. Consequently, the surface water evaporates, and the plant evapotranspiration is high. Irrigation water 
TABLE 1: Water supply and water consumption of five provinces and autonomous regions in northwest China in 2016.

\begin{tabular}{|c|c|c|c|c|c|c|}
\hline \multirow{2}{*}{$\begin{array}{l}\text { Province-level } \\
\text { administration }\end{array}$} & \multicolumn{4}{|c|}{ Water supply $\left(\times 10^{-1 \circ} \mathrm{km}^{3}\right)$} & \multicolumn{2}{|c|}{ Water consumption $\left(\times 10^{-10} \mathrm{~km}^{3}\right)$} \\
\hline & $\begin{array}{c}\text { Surface } \\
\text { water }\end{array}$ & $\begin{array}{c}\text { Ground } \\
\text { water }\end{array}$ & Others & The total amount of water supply & Agriculture & $\begin{array}{l}\text { The total amount of } \\
\text { water consumption }\end{array}$ \\
\hline Shaanxi & 55.5 & 33.3 & 2.0 & 90.8 & 57.6 & 90.8 \\
\hline Gansu & 90.5 & 24.8 & 3.0 & 118.4 & 94.7 & 118.4 \\
\hline Qinghai & 21.5 & 4.8 & 0.1 & 26.4 & 19.9 & 26.4 \\
\hline Ningxia & 59.4 & 5.3 & 0.2 & 64.9 & 56.3 & 64.9 \\
\hline Sinkiang & 445.9 & 118.6 & 0.9 & 565.4 & 533.3 & 565.4 \\
\hline
\end{tabular}

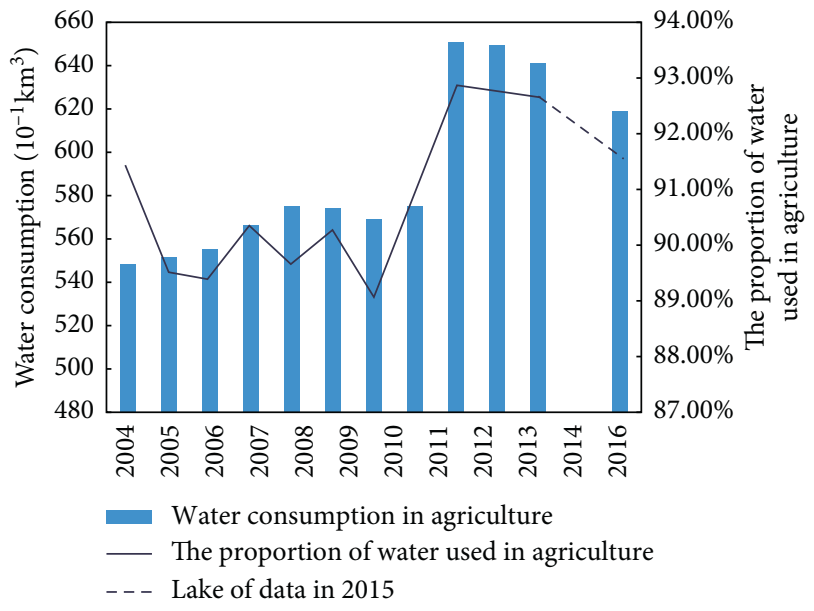

Figure 1: Agricultural water consumption of five provinces and autonomous regions in northwest China during 2004 to 2016 (China Water Resources Bulletin, 2004-2016).

infiltration is the main mechanism of groundwater recharge. The traditional extensive irrigation causes nonpoint source recharge, while the fissures induced by canal network form rapid infiltration channels. Furthermore, the agricultural crop structure has been recently adjusted to high-water consumption crops, such as fruits and vegetables, causing the underground water level to rise. Because of the low permeability of loess, the irrigation water moves through preferential migration pathways in loess, such as macroporous structures, vertical fractures, and subsurface erosion sinkholes to recharge the groundwater. When the irrigation water infiltrates quickly, the strong action owing to the potential and kinetic energy of the preferential flow expands the original preferential migration pathways and groundwater discharges as springs or runoff in slopes. With the rising of the groundwater level because of the fast recharge of irrigation water through loess fissures or sinkholes, the groundwater hydrodynamic field rapidly increases in slopes but the water level sharply drops after the discharge passes. The intense subsurface erosion makes holes inside the slopes, causing the upper slope to slump; therefore, series of landslides form along the loess plateau.

2.3. Groundwater Level Rise Induced by Irrigation. The conceptual hydrogeological model for the Heifangtai tableland is that of a block between rivers (Figure 5). In addition to irrigation, rainfall is the other groundwater recharge source. The mean annual precipitation is only $282.6 \mathrm{~mm}$ and the drought index is 5.6. The loess thicknesses in the Heifangtai area is about $20 \mathrm{~m}$ to $25 \mathrm{~m}$ [32]. Groundwater recharges as springs or seepages at the top of silty clay layers along the edges of the tableland. Because of the permeability differences between the conglomerate and silty clay layers, the groundwater moves in the conglomerate beds without any water pressure build-up [33]. Sporadic phreatic water occurs in the Cretaceous bedrock fissures. Based on numerical modelling of groundwater, the groundwater level is below the aquifer bottom in the east and west prior to irrigation and aquifer is unwatering. Large-scale irrigation started in 1968 and the groundwater level increased to $0.27 \mathrm{~m} / \mathrm{a}$, and at the center of the tableland was $0.57 \mathrm{~m} / \mathrm{a}$ before 1990. After 1990, the rate gradually slowed to about $0.25 \mathrm{~m} / \mathrm{a}$, and the cumulative rise was $20 \mathrm{~m}$ up to 2010 . It is predicted that the cumulative rise will reach $25 \mathrm{~m}$ in 2020 [33].

\subsection{Geological Hazards Induced by Irrigation in the Heifangtai} Tableland. The Heifangtai tableland has more than 40 years of irrigation by pumping and traditional broad irrigation, which induces various geological hazards including loess landslides groups and collapse of entire tableland. According to incomplete statistics, about 120 landslides have occurred (Figure 6). Consequently, irrigation canals, farmland, roads, and other facilities have been damaged as well as loss of electricity or water, traffic disruption, and heavy casualties have occurred. Landslides have resulted in about 39 deaths, 100 injuries and the relocation of 950 families, five schools, and 13 businesses. According to the official statistics, $200 \mathrm{~km}^{2}$ of farmland have been abandoned with direct economic losses of more than $2 \times 10^{8} \mathrm{RMB}$ and unaccounted indirect economic losses. The maximum loess collapse is up to $5.96 \mathrm{~m}$. Furthermore, the numerous collapse fissures, depressions, funnel-shaped sinkholes, and subsurface erosion along the edges of tableland incurred more than $2 \mathrm{~km}^{2}$ farmland loss. Water conservation structures are often seriously damaged, including residence in the villages of Xinyuan, Zhuwang, Chenjia, and Fangtai. Consequently, the local population had to relocate and build new houses every few years. Every family has refurbishment for twice a year, even five or six a year, intensifying the economic burden on residents and the local social contradictions. 


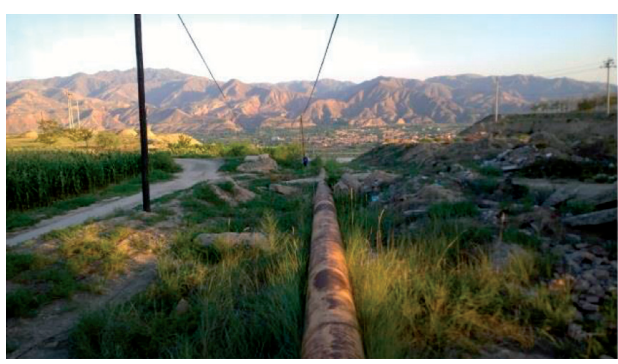

(a)

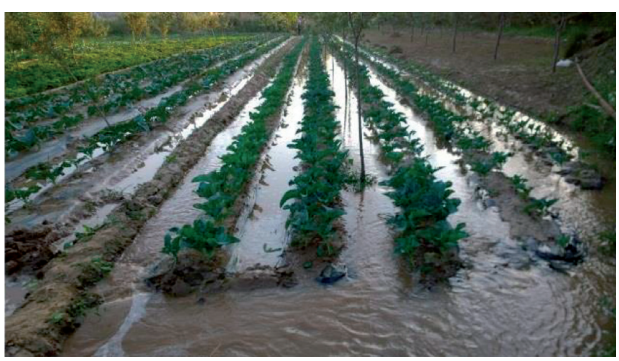

(b)

Figure 2: Agricultural irrigation in Heifangtai area. (a) Pumping engineering projects. (b) Broad irrigation.

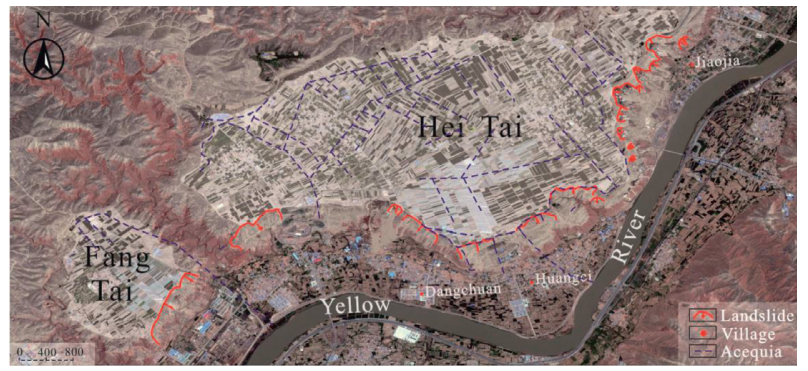

FIGURE 3: Distribution map of acequia and landslide in Heifangtai tableland of Gansu province.

\section{Research Methods}

3.1. Unsaturated Loess Test. The analysis of saturated and unsaturated seepage requires knowing the soil-water characteristic curve and the coefficient of permeability of unsaturated soil. The mechanical behaviour of unsaturated soil and the water characteristics are closely related with the soil-water characteristic curve [34]. Measurements of the soil-water characteristic test is on TRIM (soil-water characteristic fast measurement); the curves and the Hydrus-1D program were used to process moisture absorption data based on the Van Genuchten, Mualem, and suction stress models. The soil-water curve (Figure 7) for moisture absorption and dehumidification and the coefficient of the permeability function curve (HTC) were obtained [35].

The unsaturated strength of the Heifangtai loess was obtained by unsaturated triaxial shear tests in a GDS device with controlled matrix suction. Based on the Fredlund's shear strength model $[36,37]$, shear strength of unsaturated loess is given by

$$
\tau_{f}=19.0+\left(\sigma-u_{a}\right) \tan 16.2^{\circ}+\left(u_{a}-u_{w}\right) \tan 15.1^{\circ},
$$

where $\tau_{f}$ is the shear strength, $\sigma$ is the principal stress, $u_{a}$ is the pore gas pressure, and $u_{w}$ is the pore water pressure.

Figure 8 shows the Mohr circles for matrix suction of $50 \mathrm{kPa}$ and $100 \mathrm{kPa}$. Based on Figure 8, the effective cohesion of loess is $14.5 \mathrm{kPa}$, effective internal friction angle is $16.8^{\circ}$, and suction friction angle is $15.1^{\circ}$.
3.2. Numerical Simulation. The Jiaojiayatou landslide 13 was analysed to understand the slope stability under irrigation. The strata in the slope are $\mathrm{Q}_{\mathrm{p}}{ }^{3}$ loess, $\mathrm{Q}_{\mathrm{p}}{ }^{2}$ alluvial deposits, and the interface of Cretaceous sandstone and mudstone (Figure 9). The model parameters are shown in Table 2. Based on the engineering geological profile, we built the saturated-unsaturated finite-element model in Figure 10. The model height is $80 \mathrm{~m}$ and the width is $135 \mathrm{~m}$ at the top and $223 \mathrm{~m}$ at the bottom. The bottom is horizontal and constrained on both sides, but the surface is free. The water level is fixed at the left; that is, a waterhead is set on the left to simulate the groundwater level under different irrigation conditions. The bottom is the confining boundary, and the slope surface is the seepage surface boundary.

In general, soil intensity under the groundwater level uses saturated intensity in slope stability analysis, and that above the groundwater level uses shear strength at natural water content or plastic limit water content. But partly shear strength induced by the negative pore pressure under the groundwater level is usually ignored. It is unreasonable for the landslides at which the sliding surface above the groundwater level because soil intensity and matric suction drop when groundwater level increases. Therefore, matrix suction distribution in the slope and shear strength of unsaturated soil should be considered during the slope stability analysis. The paper takes unsaturated theory to study the problem. FLAC ${ }^{3 \mathrm{D}}$ is used in stability calculation program, the function of unsaturated stability analysis is developed through FISH programming language of FLAC ${ }^{3 \mathrm{D}}$ software, filled in the lacuna of unsaturated seepage analysis and the properties of unsaturated materials.

\section{Results and Discussion}

4.1. Seepage Characteristics in Slope under Uniform Infiltration. The groundwater level rise is slow; therefore, steady flow is used and different groundwater levels are used to simulate the seepage owing to irrigation. The phreatic water in the loess is $31-56 \mathrm{~m}$. The loess layer is dry when the groundwater level is lower than that of the aquifer prior to irrigation. We calculate the saturated and unsaturated seepage and then the pore pressure distribution in the slope (Figure 11). 


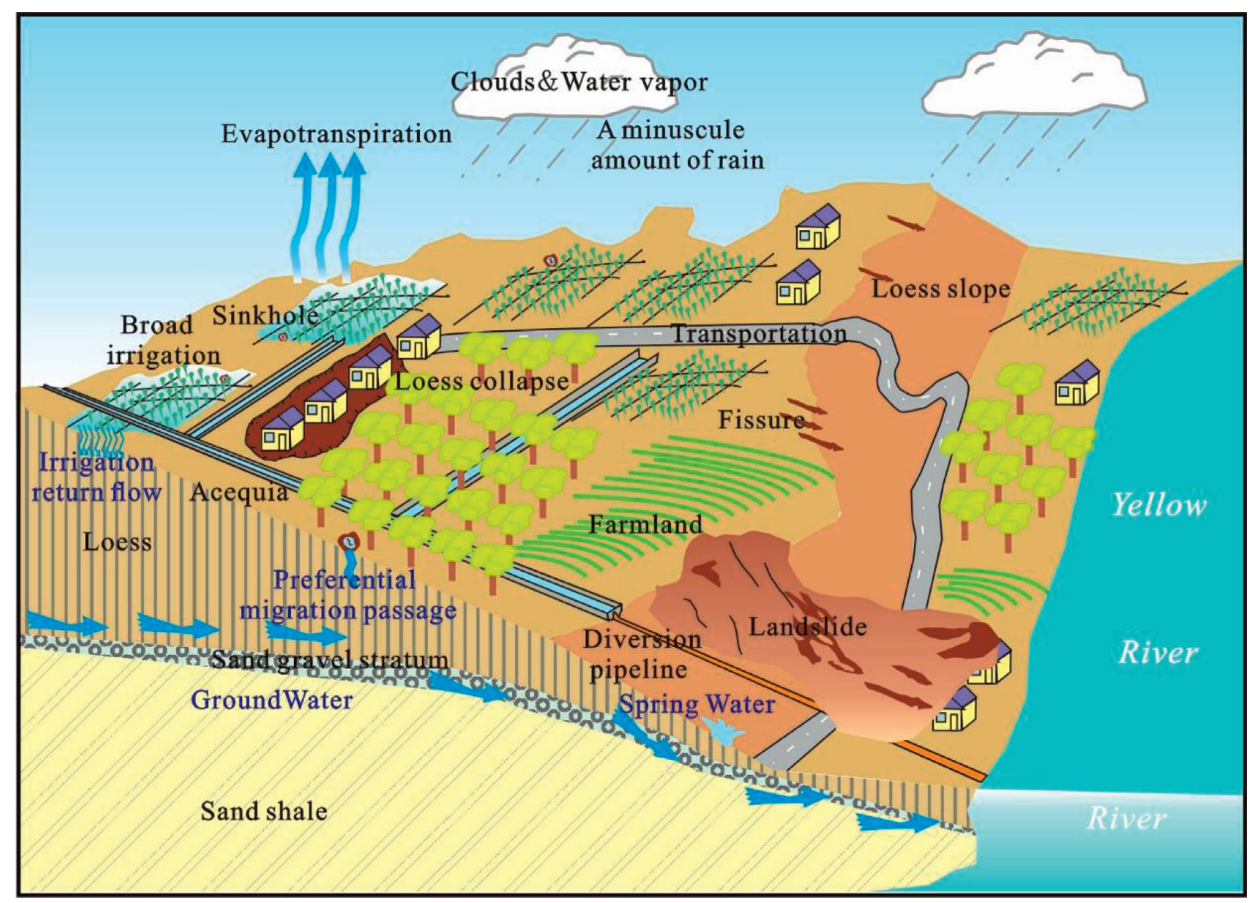

FIGURE 4: Irrigation water infiltration mode.

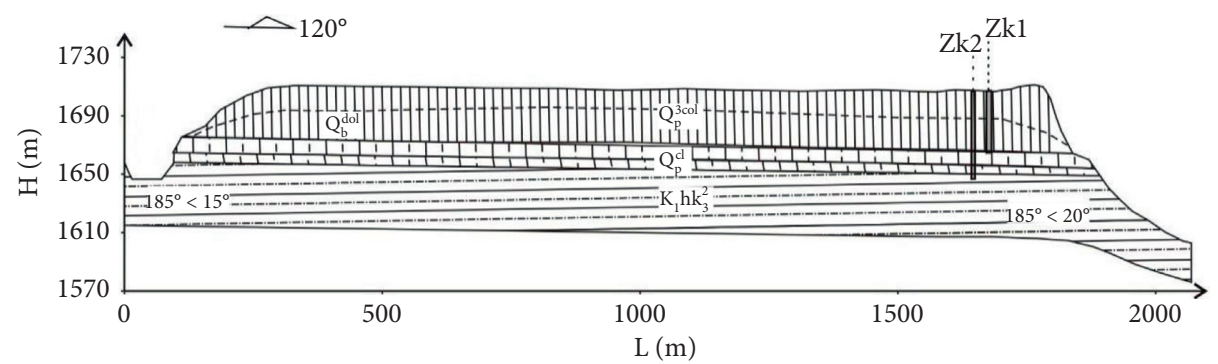

Figure 5: The hydrogeological model for the Heifangtai tableland.

At the beginning of irrigation, there is no stable groundwater level in the loess and the isoline of the pore pressure is nearly horizontal (Figure 11(a)). The groundwater level rises with increasing irrigation and irrigation time, which causes the bottom of the loess to become saturated and the groundwater to flow slowly from the inner saturated zone to the unsaturated zone under the influence of matrix suction. The velocity of the increase in pore pressure in the slope is greater than that horizontally and pore pressure is decreased. With increasing groundwater level, the water content in the unsaturated zone increases, and the pore pressure in the unsaturated zone and the saturated area increases as well. In addition, the hydraulic gradient in the slope and the seepage velocity increases, which increases the water flow at the slope and decreases the slope stability.

Figure 12 shows the distribution curves of the matrix suction in the slope under different groundwater levels. Figure 12(a) shows that the groundwater level rises in the slope with rising groundwater level, whereas the matrix suction decreases linearly with respect to the water table.
Based on the shear strength model of Fredlund, the decrease in matrix suction decreases the shear strength and thus the slope stability also decreases.

4.2. Seepage in Slope under Infiltration. First, the method of unsteady flow is adopted to calculate the seepage inside the slope with different fracture locations. Figure 13 shows the distribution of pore water pressure at $33 \mathrm{~m}, 15 \mathrm{~m}$, and $5 \mathrm{~m}$, respectively, which is the distance between the fracture location and the edge of the pier after 60 days. A channel forms near the fracture because the pore water pressure increases as irrigation water seeps through. With time, the pore water pressure increases $2 \mathrm{~m}$ around the fracture and a saturated zone forms locally. In addition, the closer the fracture is to the edge of the platform, the higher the pore pressure is when the water seepage flows into the potential sliding surface.

The matrix suction varies greatly; inside the slope, it is almost constant, whereas near the fracture, it decreases significantly (Figure 14). A large amount of water is injected 


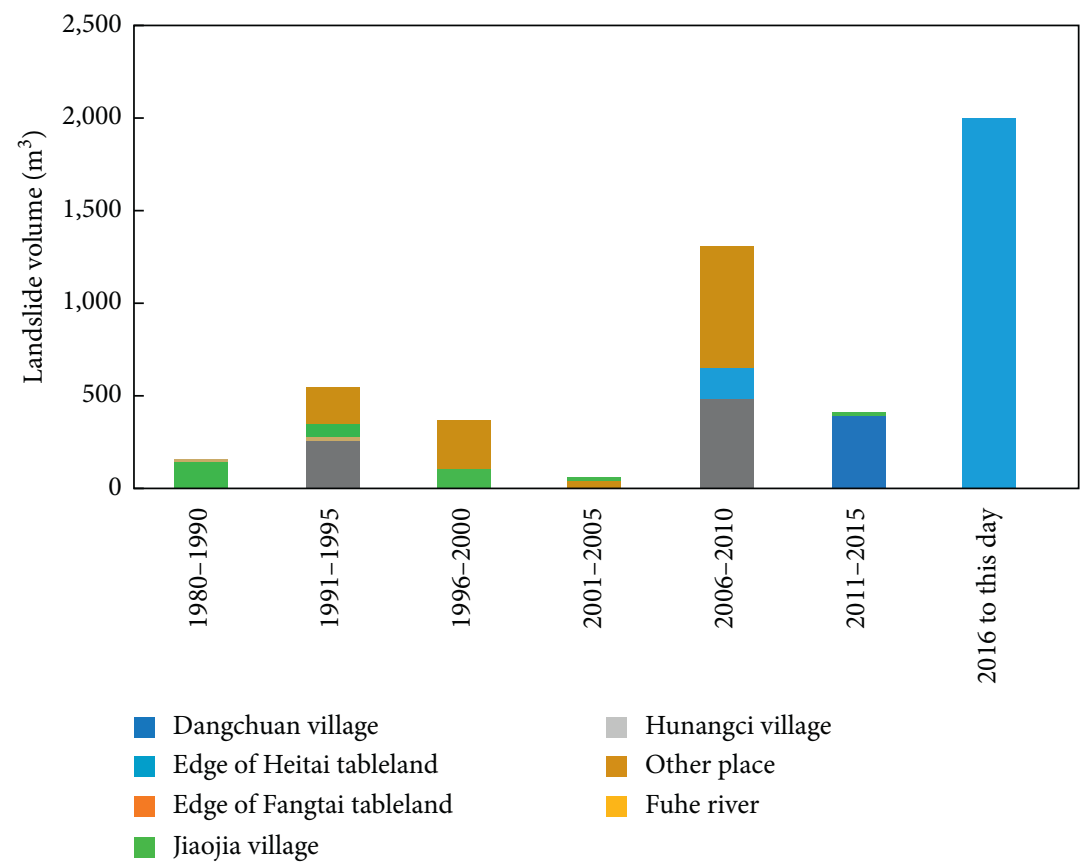

Figure 6: Loess landslide statistics of Heifangtai tableland from 1980 to now.

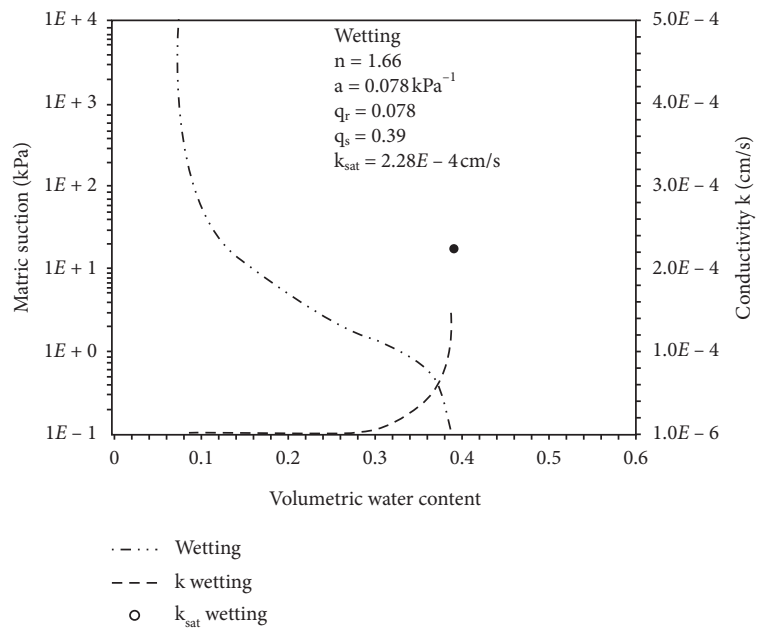

Figure 7: The soil-water curve for moisture absorption and dehumidification and the coefficient of the permeability function curve (HTC).

into the fissure and causes the soil recharge near the fissure to increase dramatically. The permeability of loess is low and there is no obvious upward movement of the groundwater level in the slope but an obvious saturation zone forms in the fissure based on the groundwater level line at matrix suction of $0 \mathrm{kPa}$.

Figure 15 shows the distribution of pore water pressure inside the slope at different fractures after 60 days of flooding. The increase in the number of fissures increases the pore water pressure in the fractured area. The fractures little affect the groundwater level ( $0 \mathrm{kPa}$ contour line) based on the distribution of matrix suction as a function of the different number of cracks (Figure 16). This is due to the poor

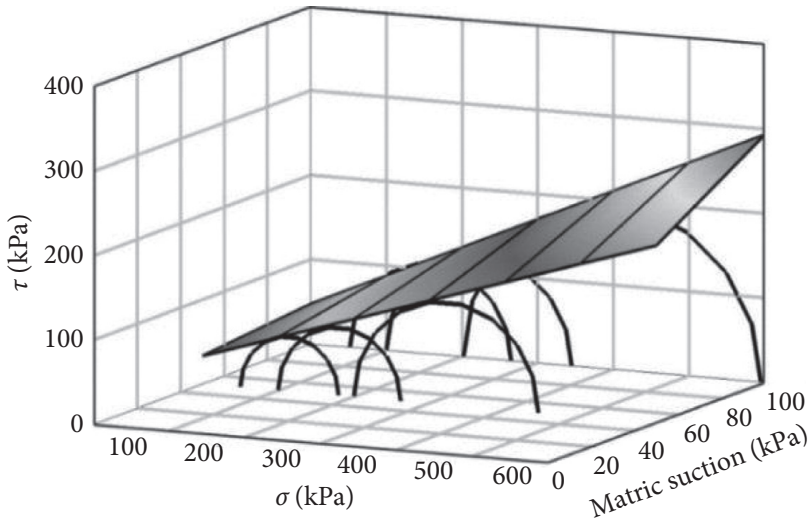

Figure 8: The Mohr circles of shear strength of unsaturated loess.
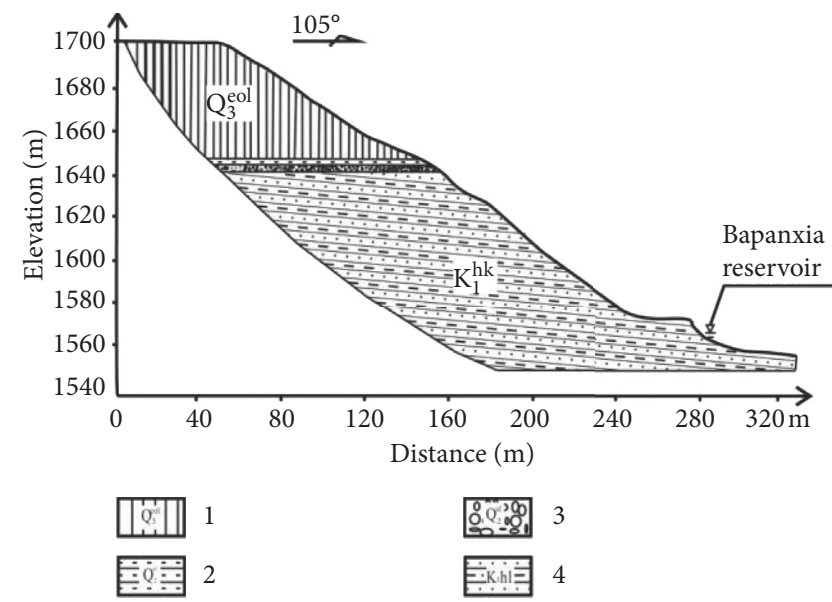

FIGURE 9: Engineering geological profile of landslide (1: loess; 2: silty clay; 3 : sand and gravel; and 4: sandy mudstone interbedding). 
TABLE 2: Material parameters of the model $[1,2]$.

\begin{tabular}{|c|c|c|c|c|c|c|c|c|c|}
\hline \multirow[t]{2}{*}{ Title } & \multirow{2}{*}{$\begin{array}{c}\text { Weight } \\
\rho / \mathrm{kN}\left(\mathrm{m}^{3}\right)\end{array}$} & \multirow{2}{*}{$\begin{array}{l}\text { Elasticity } \\
\text { modulus } E \\
(\mathrm{MPa})\end{array}$} & \multirow[t]{2}{*}{ Poisson's ratio $\mu$} & \multirow[t]{2}{*}{ Porosity } & \multicolumn{2}{|c|}{$\begin{array}{c}\text { Permeability } \\
\text { coefficient }(\mathrm{m} / \mathrm{d})\end{array}$} & \multirow{2}{*}{$\begin{array}{c}\text { Cohesion } \\
c(\mathrm{kPa})\end{array}$} & \multirow{2}{*}{$\begin{array}{c}\text { Internal } \\
\text { friction } \\
\text { angle } \varphi\left({ }^{\circ}\right)\end{array}$} & \multirow{2}{*}{$\begin{array}{c}\text { Suction } \\
\text { friction } \\
\text { angle } \varphi^{\mathrm{b}}\left(^{\circ}\right)\end{array}$} \\
\hline & & & & & Vertical & Horizonal & & & \\
\hline Loess & 15.2 & 46 & 0.35 & 0.51 & 0.12 & $2.4 e-2$ & 14.5 & 16.8 & 15.1 \\
\hline Silty clay & 19.5 & 90 & 0.3 & 0.30 & $2 e-4$ & $2 e-4$ & 60.0 & 22.0 & - \\
\hline Sand and gravel & 20.0 & 140 & 0.3 & 0.40 & 2.0 & 2.0 & - & - & - \\
\hline $\begin{array}{l}\text { Sandy mudstone } \\
\text { interbedding }\end{array}$ & 22.0 & 200 & 0.3 & 0.10 & $1 e-5$ & $1 e-5$ & - & - & - \\
\hline
\end{tabular}

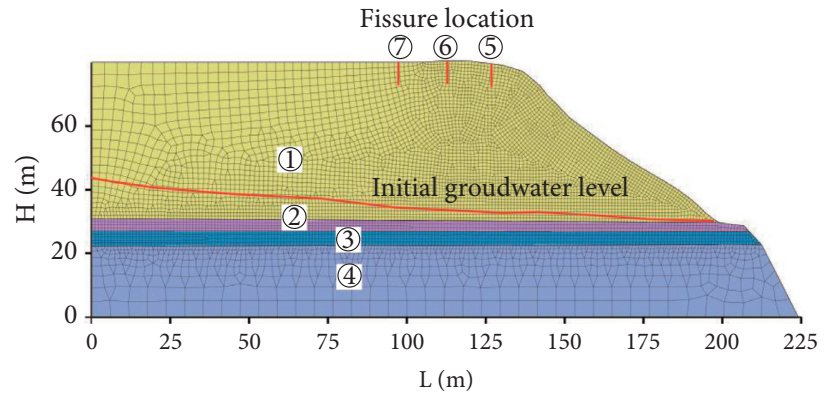

Figure 10: The calculation model (1) loess; (2) silty clay; (3) sand and gravel; (4) sandy mudstone interbedding; and (5),(6), and (7) the distance between the fracture location and the edge of the pier is $5 \mathrm{~m}, 15 \mathrm{~m}$, and $33 \mathrm{~m}$ ).

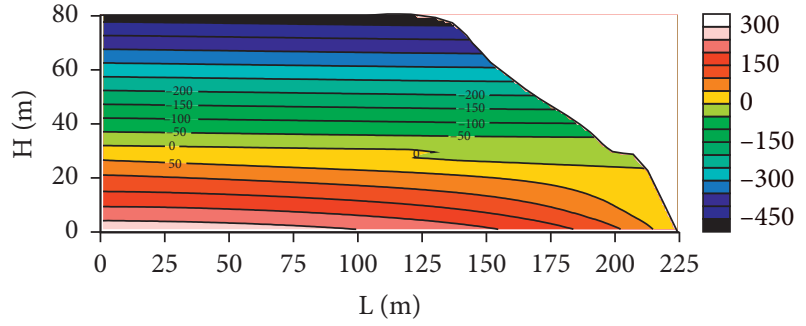

(a)

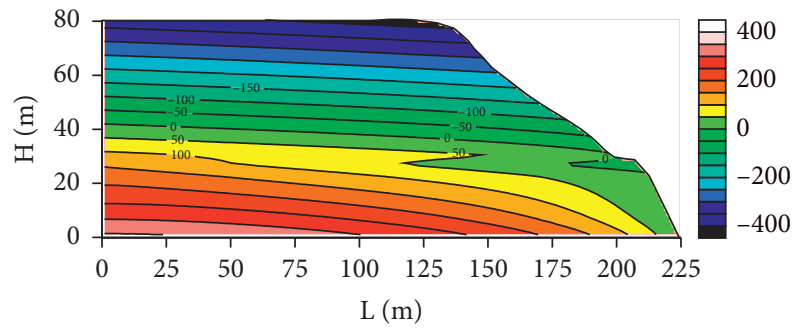

(c)

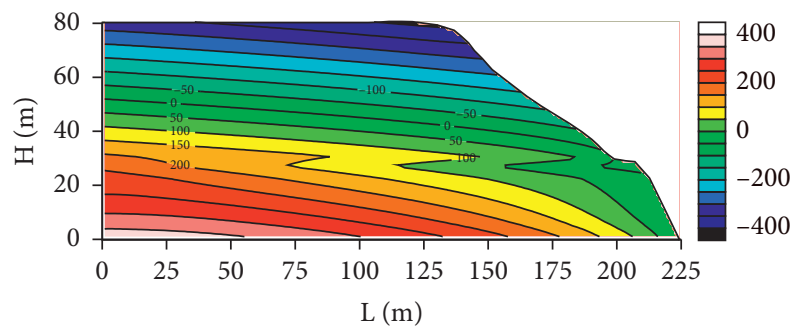

(e)

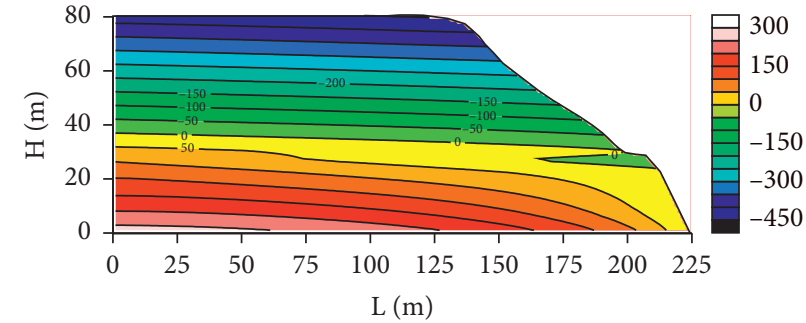

(b)

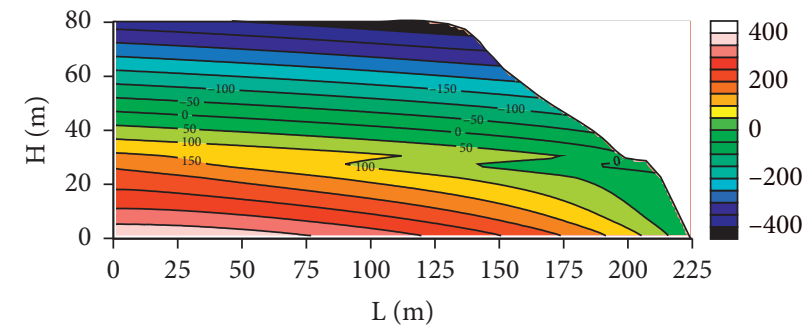

(d)

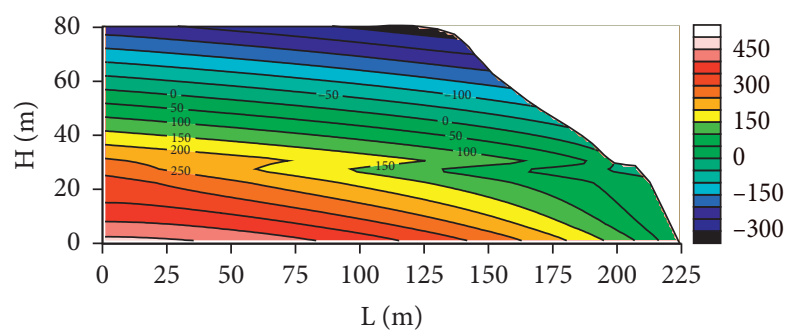

(f)

FIGURE 11: The distribution of pore pressure of different groundwater level. (a) $31 \mathrm{~m}$. (b) $36 \mathrm{~m}$. (c) $41 \mathrm{~m}$. (d) $46 \mathrm{~m}$. (e) $51 \mathrm{~m}$. (f) $56 \mathrm{~m}$. 


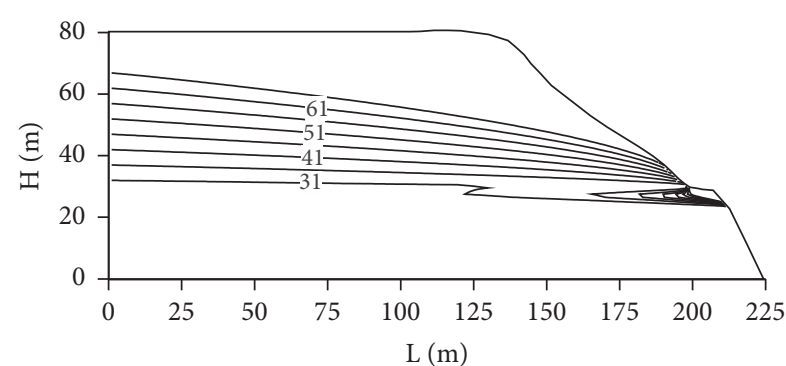

(a)

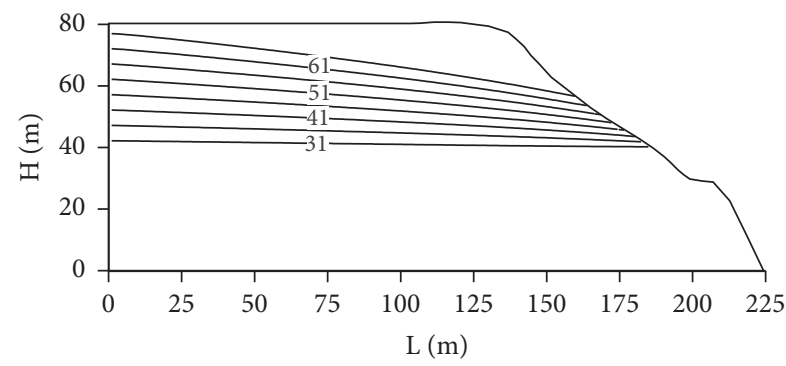

(c)

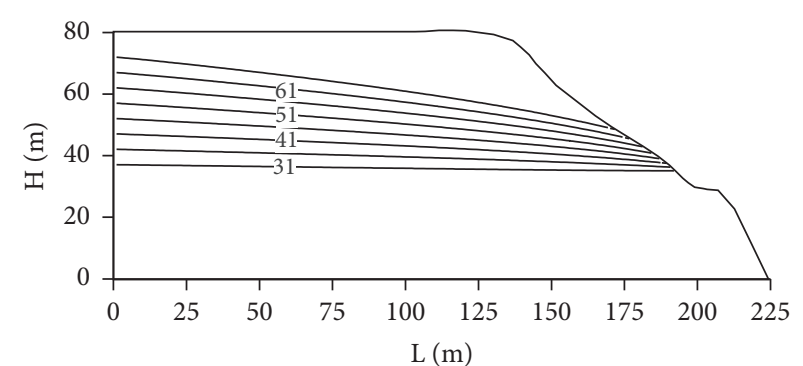

(b)

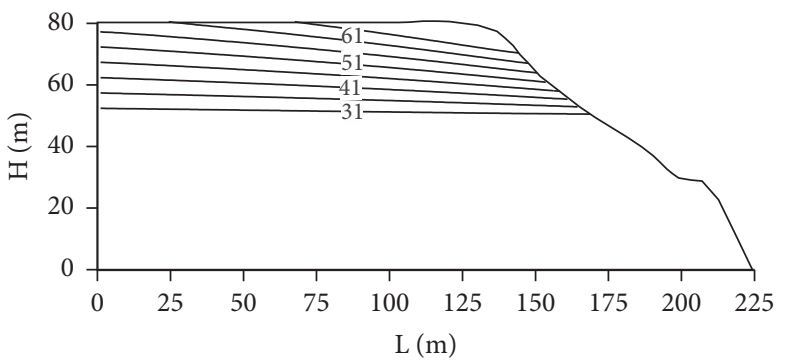

(d)

Figure 12: The relationship between groundwater and matric suction. (a) $0 \mathrm{kPa}$. (b) $50 \mathrm{kPa}$. (c) $100 \mathrm{kPa}$. (d) $200 \mathrm{kPa}$.

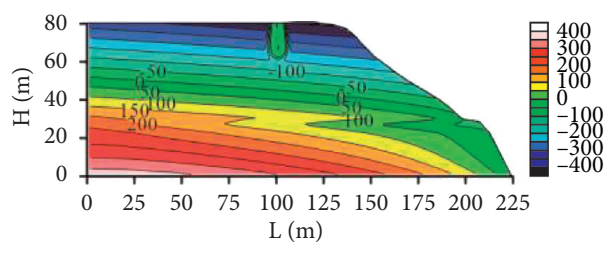

(a)

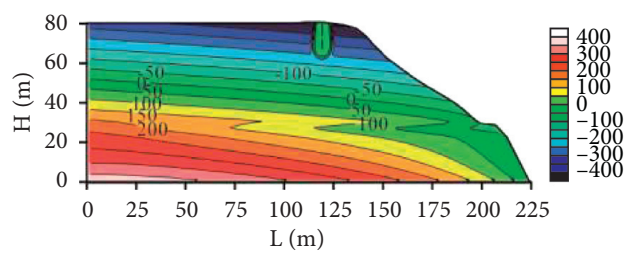

(b)

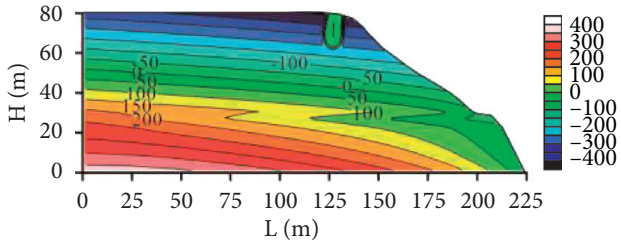

(c)

Figure 13: Distribution of pore pressure $(\mathrm{kPa})$ in the slope body at different fissure locations. (a), (b), and (c) The distance between the fracture location and the edge of the pier is $33 \mathrm{~m}, 15 \mathrm{~m}$, and $5 \mathrm{~m}$.

permeability of the loess; however, the pore water pressure near the fissure increases rapidly and a saturated zone forms as the seepage flow in loess and the infiltration of groundwater decreases. With increasing the number of fractures and loess collapsibility, sinkholes form in the area and then landslides are induced. This is due to the rapid decrease in slope stability over short time, whereas the infiltration of irrigation water and the water recharge in the surface soil increase fast.

4.3. Mechanism of Loess Landslide Induced by Irrigation. Based on the laboratory test results and field monitoring, the loess landslide pattern induced by irrigation is shown in Figure 17. Before irrigation (Figure 17(a)), the groundwater level is below the aquifer, which is unwatering with some exceptions in the low-lying areas in the middle of the tableland and a few fissures at the edges of the tableland. This is why such few landslides occur before irrigation.

At the beginning of irrigation, there is no stable groundwater level in the loess tableland and the pore pressure contours in the slope are horizontal. With increasing irrigation times, some areas develop migration pathways, such as fissures and sinkholes, owing to the loess collapsibility. The irrigated water rapidly recharges groundwater through preferential migration pathways (Figure 17(b)) and the groundwater level rises, while the bottom of the loess becomes saturated (Figure 17(c)). The underground runoff slowly flows from the saturation zone to the unsaturated zone because of the matrix suction; 


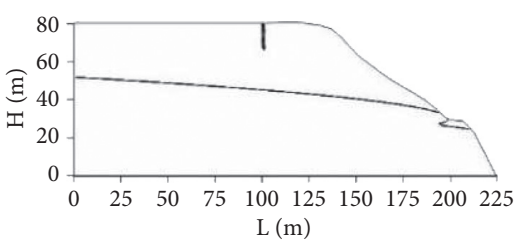

(a)

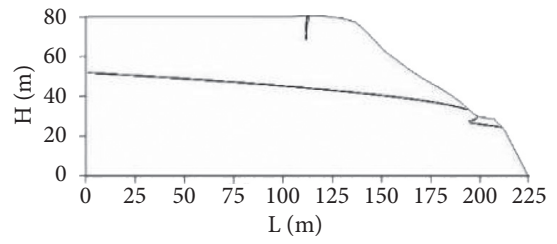

(b)

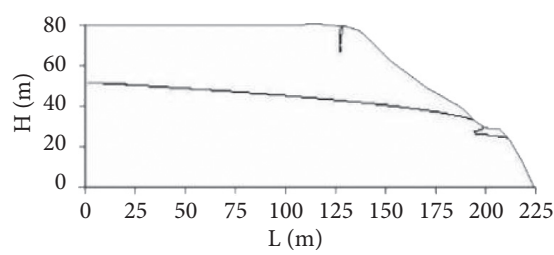

(c)

Figure 14: Distribution curve of matric suction $(\mathrm{kPa})$ in the slope at different fissure locations. (a), (b), and (c) The distance between the fracture location and the edge of the pier is $33 \mathrm{~m}, 15 \mathrm{~m}$, and $5 \mathrm{~m}$.

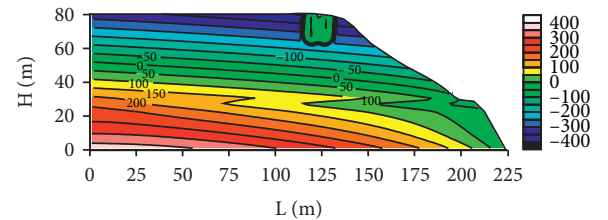

(a)

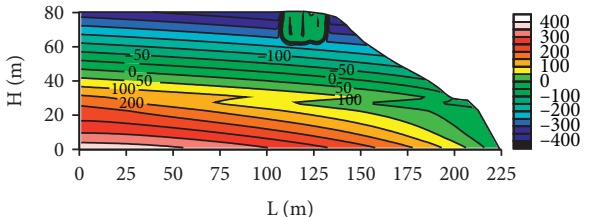

(b)

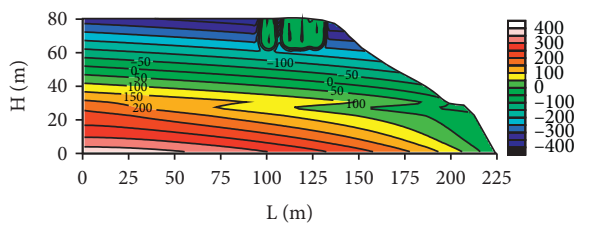

(c)

FIGURE 15: Distribution of pore pressure $(\mathrm{kPa})$ in the slope body of different number of fissures ((a) two fissures; (b) three fissures; and (c) four fissures).

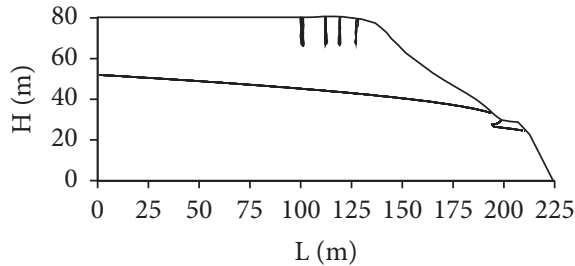

(a)

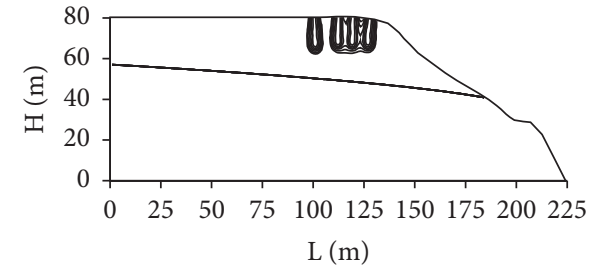

(b)

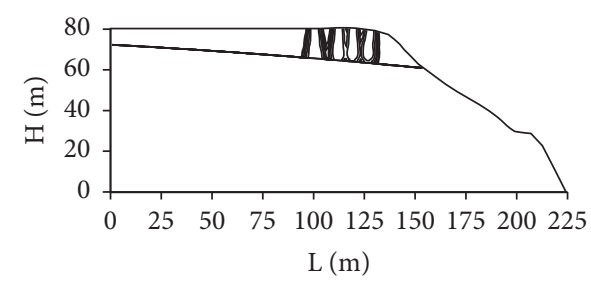

(c)

Figure 16: Distribution curve of matric suction $(\mathrm{kPa})$ in the slope of different number of fissures (a), (b), and (c) matric suction at $0 \mathrm{kPa}$, $50 \mathrm{kPa}$, and $200 \mathrm{kPa}$.

furthermore, the increase in the pore pressure away from the edge of slope is faster than it is close to the edge and deflection of the pore pressure contours is seen. With rising groundwater level, the quantity flowing to the unsaturated zone and the pore pressure increase and, consequently, the saturation zone becomes larger (Figure 17(d)). The hydraulic gradient of the slope increases owing to the rising groundwater level and seepage velocity is thus greater than before. Because of the engineering properties of the loess, broad irrigation induces more fissures at the edge of the tableland, with many small saturation zones around the fissures. Thus, the loess strength decreases over time and 


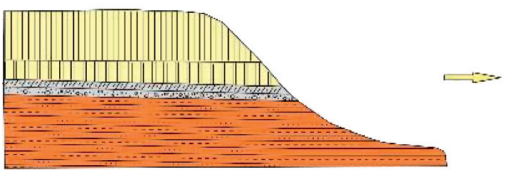

(a)

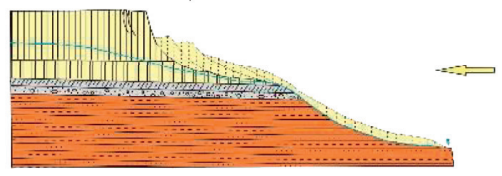

(f)

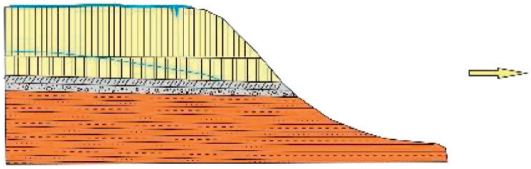

(b)

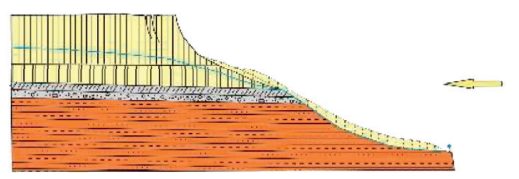

(e)

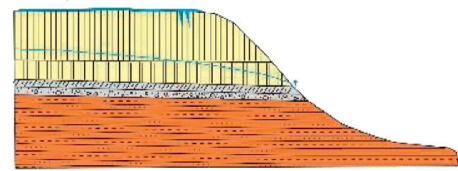

(c)

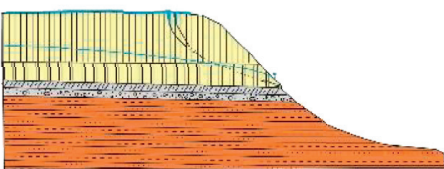

(d)
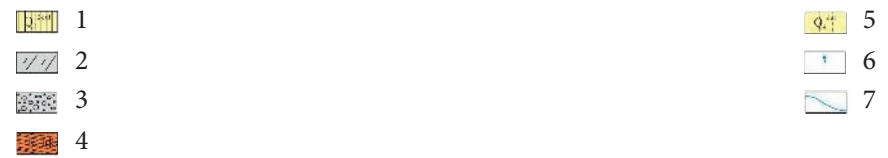

Figure 17: The failure mode of loess landslide induced by irrigation (1: loess; 2: silty clay; 3 : sand and gravel; 4: sandy mudstone interbedding; 5: landslide deposits; 6: spring; and 7: groundwater level).

latent sliding surfaces form near the slope edges (Figure 17(e)). When the saturation zone expands to a certain extent, the stability of the loess slope rapidly decreases and landslides occur (Figure 17(f)).

Increased irrigation water infiltration through preferential migration pathways induces landslides in the Heifangtai tableland. The groundwater level rise leads to matrix suction and strength decreases and loess slope instability.

\section{Conclusions}

We studied the landslide mechanism induced by irrigation in loess, using the Heifangtai tableland as the study area. The main conclusions are the following:

First, agriculture in arid and semiarid regions mainly relies on irrigation. Traditional broad irrigation wastes fresh water; moreover, irrigation water infiltration and preferential migration pathways change the hydrogeological conditions in the irrigated areas and induce landslides, collapses, and mudflows.

Second, the groundwater level is below the aquifer before irrigation. Moreover, after long-term broad irrigation, the groundwater level rise decreases the loess matrix suction and strength and increases the loess slope instability.

Finally, based on the loess landslide mechanism induced by irrigation in arid and semiarid regions, countermeasures are proposed. First, the traditional broad irrigation with water-saving irrigation methods should be replaced. Second, more drought-resistant crops should be planted. Third, the groundwater level should be lowered. Fourth, monitoring and early warning of loess landslides in the main growth area should be intensified.

Geological hazards, such as landslides, collapses, and soil salinization, are induced by outdated irrigation methods, such as broad irrigation and oven filling. Based on the loess landslide mechanism induced by irrigation in arid and semiarid regions, four countermeasures are proposed. Firstly, replace the traditional broad irrigation by water-saving irrigation methods, such as trickle irrigation. Secondly, drought-resistant crops that require less water should be planted. Thirdly, lower the groundwater level. Fourthly, intensify monitoring and early warning in the central growth area.

\section{Data Availability}

The data used to support the findings of this study were supplied by Jiading Wang under license and so cannot be made freely available. Requests for access to these data should be made to Jiading Wang (e-mail: wangjiading029@ 163.com).

\section{Conflicts of Interest}

The authors declare that they have no conflicts of interest regarding the publication of this paper.

\section{Acknowledgments}

The research of this paper was funded by the State Key Program of the National Natural Science Foundation of China (Grants nos. 41630639 and 41372329).

\section{References}

[1] T. Gu, J. Wang, C. Wang, Y. Bi, Q. Guo, and Y. Liu, "Experimental study of the shear strength of soil from the heifangtai platform of the loess plateau of China," Journal of Soils and Sediments, vol. 19, no. 10, pp. 3463-3475, 2019.

[2] T.-f. Gu, M.-s. Zhang, J.-d. Wang, C.-x. Wang, Y.-j. Xu, and $\mathrm{X}$. Wang, "The effect of irrigation on slope stability in the Heifangtai Platform, Gansu Province, China," Engineering Geology, vol. 248, pp. 346-356, 2019.

[3] A. Oktem, M. Simsek, and A. G. Oktem, "Deficit irrigation effects on sweet corn (zea mays saccharata sturt) with drip irrigation system in a semi-arid region: i. water-yield 
relationship," Agricultural Water Management, vol. 61, no. 1, pp. 63-74, 2003.

[4] T. Rebecka and J. Jarsjö, "Water savings through improved irrigation techniques: basin-scale quantification in semi-arid environments," Water Resources Management, vol. 26, pp. 949-962, 2012.

[5] Y. Tian, B. Wu, Y. Zheng, X. Wu, J. Liu, and C. Zheng, "Modeling surface water-groundwater interaction in arid and semi-arid regions with intensive agriculture," Environmental Modelling \& Software, vol. 63, pp. 170-184, 2015.

[6] L. Xu, F. Dai, X. Tu, L. G. Tham, Y. Zhou, and J. Iqbal, "Landslides in a loess platform, North-west China," Landslides, vol. 11, no. 6, pp. 993-1005, 2014.

[7] J. Peng, P. Sun, O. Igwe, and X. Li, "Loess caves, a special kind of geo-hazard on loess plateau, Northwestern China," Engineering Geology, vol. 236, pp. 79-88, 2018.

[8] D. Zhang, G. Wang, C. Luo, J. Chen, and Y. Zhou, "A rapid loess flowslide triggered by irrigation in China," Landslides, vol. 6, no. 1, pp. 55-60, 2009.

[9] J. huang, J. Peng, G. Wang, I. Javed, Y. Wang, and W. Li, "Distribution and characteristics of landslide in loess plateau: a case study in Shaanxi province," Engineering Geology," Engineering Geology, vol. 236, pp. 89-96, 2017.

[10] K. Beven and P. Germann, "Macropores and water flow in soils," Water Resources Research, vol. 18, no. 5, pp. 1311-1325, 1982.

[11] P. Germann and K. Beven, "Water flow in soil macropores, I. An experimental approach," European Journal of Soil Science, vol. 32, no. 1, pp. 1-13, 2010.

[12] H. H. Gerke and M. T. Van Genuchten, "A dual-porosity model for simulating the preferential movement of water and solutes in structured porous media," Water Resources Research, vol. 29, no. 29, pp. 305-319, 2010.

[13] L. Xu, F. C. Dai, L. G. Tham et al., "Field testing of irrigation effects on the stability of a cliff edge in loess, north-west China," Engineering Geology, vol. 120, no. 1-4, pp. 10-17, 2011.

[14] M. S. Zhang and T. L. Li, "Triggering factors and forming mechanism of loess landsides," Journal of Engineering Geology, vol. 19, no. 4, pp. 530-540, 2011.

[15] J. N. Hutchinson, "General report: morphological and geotechnical parameters of landslides in relation to geology and hydrogeology," International Journal of Rock Mechanics and Mining Sciences \& Geomechanics Abstracts, vol. 19, no. 1, pp. 91-97, 1988.

[16] K. Sassa, "Mechanisms of landslide triggered debris flows," Environmental Forest Science, vol. 54, pp. 499-518, 1998.

[17] J. D. Wang and Y. H. Hui, "Systems analysis on Heifangtai loess landslide in crows induced by irrigated water," Bulletin of Soil and Water Conservation, vol. 21, no. 3, pp. 10-12, 2001.

[18] J. D. Wang, S. F. Xiao, and Z. Y. Zhang, "The mechanism for movement of irrigation-induced high-speed loess landslide," Journal of Engineering Geology, vol. 9, no. 3, pp. 241-246, 2001.

[19] J. D. Wang and Y. H. Hui, "Landslides in crows induced by irrigated water in loess area," Scientia Geographica Sinica, vol. 22 , no. 3, pp. 305-310, 2002.

[20] J. D. Wang, "A mechanism of high-speed loess landslidessaturated loess creeping liquefy action," Geological Review, vol. 38, no. 6, pp. 532-539, 1992.

[21] J. D. Wang and Z. Y. Zhang, "A study on the mechanism of high-speed loess landslide induced by earthquake," Chinese Journal of Geotechnical Engineering, vol. 21, no. 6, pp. 670674, 1999.
[22] Y. F. Zhou, L. G. Tham, W. M. Yan, F. C. Dai, and L. Xu, "Laboratory study on soil behavior in loess slope subjected to infiltration," Engineering Geology, vol. 183, pp. 31-38, 2014.

[23] M.-W. Gui and Y.-M. Wu, "Failure of soil under water infiltration condition," Engineering Geology, vol. 181, pp. 124141, 2014.

[24] L. Xu, F. C. Dai, X. B. Tu et al., "Occurrence of landsliding on slopes where flowsliding had previously occurred: an investigation in a loess platform, North-west China," Catena, vol. 104, no. 5, pp. 195-209, 2013.

[25] Q. Feng, G. D. Cheng, and M. K. Masao, "Trends of water resource development and utilization in arid north-west China," Environmental Geology, vol. 39, no. 8, pp. 831-838, 2000.

[26] Y. Leng, J. Peng, Q. Wang, Z. Meng, and W. Huang, "A fluidized landslide occurred in the loess plateau: a study on loess landslide in south jingyang tableland," Engineering Geology, vol. 236, pp. 129-136, 2018.

[27] J. Peng, G. Wang, Q. Wang, and F. Zhang, "Shear wave velocity imaging of landslide debris deposited on an erodible bed and possible movement mechanism for a loess landslide in Jingyang, Xi'an, China," Landslides, vol. 14, no. 4, pp. 1503-1512, 2017.

[28] W. J. Wu, X. Su, and X. M. Meng, "Characteristics and origin of loess landslides on loess terraces at heifangtai, gansu province, China," Applied Mechanics and Materials, vol. 694, pp. 455-461, 2014.

[29] L. Xu, F. C. Dai, Q. M. Gong, L. G. Tham, and H. Min, "Irrigation-induced loess flow failure in Heifangtai Platform, north-west China," Environmental Earth Sciences, vol. 66, no. 6, pp. 1707-1713, 2012.

[30] F. Wen-Kai, D. U. Jie, Y. C. Shi, Q. Chen, C. L. Wei, and L. I. Chang-Shun, "Evaluation and prediction after earthquake of the yikeyin debris flow," Research of Soil \& Water Conservation, vol. 17, no. 6, pp. 68-44, 2010.

[31] D. Zhang, G. Wang, C. Luo, J. Chen, and Y. Zhou, "A rapid loess flowslide triggered by irrigation in China," Landslides, vol. 6, no. 1, pp. 55-60, 2008.

[32] C. L. Zhang, P. Li, T. L. Li, and M. S. Zhang, "In situ observation on regularities of rainfall infiltration in loess," Journal of Hydraulic Engineering, vol. 45, no. 6, pp. 728-734, 2014.

[33] T. F. Gu, L. F. Zhu, W. Hu, J. D. Wang, and Y. M. Liu, "Effect on slope stability due to groundwater rising caused by irrigation: a case study of Heifang Platform in Gansu, China," Geoscience, vol. 2, pp. 408-413, 2015.

[34] A. A. Heshmati and M. R. Motahari, "Modeling the dependency of suction stress characteristic curve on void ratio in unsaturated soils," KSCE Journal of Civil Engineering, vol. 19, no. 1, pp. 91-97, 2015.

[35] N. Lu, A. Wayllace, and S. Oh, "Infiltration-induced seasonally reactivated instability of a highway embankment near the Eisenhower Tunnel, Colorado, USA," Engineering Geology, vol. 162, no. 2, pp. 22-32, 2013.

[36] D. G. Fredlund, N. R. Morgenstern, and R. A. Widger, "The shear strength of unsaturated soils," Canadian Geotechnical Journal, vol. 15, no. 3, pp. 313-321, 1978.

[37] D. G. Fredlund, A. Xing, M. D. Fredlund, and S. L. Barbour, "The relationship of the unsaturated soil shear strength to the soil-water characteristic curve," Canadian Geotechnical Journal, vol. 33, no. 3, pp. 440-448, 1996. 